\title{
Psychosocial Adjustment among Adolescents with Congenital Heart Diseases in Benha City
}

\author{
Samar Ezat El-Sarawy1, Mervat Hosny Shalaby2, Doha Abd El-Basser Mahmoud3
}

\author{
(1) Nursing Specialist in Sirs El-Lian Hospital, Egypt, (2) Professor of Psychiatric and Mental \\ Health Nursing, Faculty of Nursing, Tanta University, Egypt and (3) Lecturer of Psychiatric and \\ Mental Health Nursing, Faculty of Nursing, Benha University, Egypt
}

\begin{abstract}
Background: Congenital heart disease is a long -term condition that can affect physical, psychological and social function. Aim of study: Was to explore the psychosocial adjustment among adolescents with congenital heart diseases. Research design: A descriptive research design was utilized to achieve the aim of the study. Setting: The study was conducted at cardiology department and cardiac outpatient clinic at Benha University Hospital. Sample: Convenience sample consisted of 100 patients with congenital heart disease. Tools: Two tools were utilized. (1): Structured interview questionnaire, (2): Psychosocial adjustment patterns among patients with congenital heart disease. Results: About three fifth of the studied patients are little using about methods of psychosocial adjustment patterns (seek support and avoidance methods), while two fifth of them are high using about active adaptation methods. Conclusion: There are highly positive correlations between total psychosocial adjustment patterns of the studied patients. Recommendations: Providing psychosocial counseling in which psychological support for patients and their families help them to identify strengths, abilities and resources in order to contribute to positive adjustment and healthy outcomes.
\end{abstract}

Keywords: Congenital heart disease, Psychosocial adjustment.

\section{Introduction}

Congenital Heart Disease (CHD) is a problem with the structure of the heart. It is present at birth. Congenital heart diseases are the most common type of birth defects. The defects can involve the wall of the heart, the valves of the heart, and the arteries and veins near the heart. They can disrupt the normal flow of blood through the heart. The blood flow can slow down, go in the wrong place, or be blocked completely (American Heart Association, 2019).

Adjusting to congenital heart disease through helping the adolescents to set realistic goals and identify personal skills and knowledge. Involve the adolescent in decision making helps him move toward independence, improving the psychosocial functioning quality of life among adolescents with CHDs, helping them feel normal when managing patients' suffering. The psychiatrics suggested that a feeling of optimism was the most important factor in reducing CHD patients' depression and anxiety and that good social support and a strong sense of coherence were important for psychosocial stability. Good psychosocial adaptation of congenital heart disease patients appeared to be the result of close family relationships, and a strong sense of coherence (Wang et al., 2020).

The nursing role of adjustment among adolescents with congenital heart disease is that the sensitive counseling and health education by nurses can promote the physical health and psychosocial adaptation of adolescents with congenital heart disease (Barrat, 2018). Nurses should counsel each adolescent about sports participation based on 
individual basis and academic performance. Nurses should assess their feeling toward drugs and alcohol to help them not to use these substances (Daliento, 2018). Nurses should determine the quality of support systems available to adolescents with congenital heart disease, recognize social concerns and reinforce positive coping responses. Nurses should guide these adolescents about high risk behavior avoidance, teen pregnancy avoidance, fostering independence, coordination of care, encourage medication compliance. Also, nurse should provide family with information about adolescent condition (Gaskin \& Kennedy, 2019).

\section{Significance of the study}

In Egypt, twenty thousand children were born annually with congenital heart defects. It was found that the number of children who have been detained with congenital heart defects during the year 2018 about 3,000 children including 133 patients aged between 10 to 21 years (Medical report at University Hospital, 2018). There were difficulties face adolescents with congenital heart disease such as coping with illness and physical limitations, social exclusion, discrimination and bullying, challenge of normality, aggression, anger or withdrawal, uncertainty about the future (Cohen et al., 2017). High rates of survival in congenital heart disease allowed patients to face different challenges in life cycle, and made the topic of adjustment central in health care (American heart association, 2018). In my opinion, this study is important because it would help to identify the psychosocial adjustment among adolescent with heart disease.

\section{Aim of the study}

This study aimed to explore the psychosocial adjustment among adolescents with congenital heart diseases.

\section{Research question:}

What the level of psychosocial adjustment among adolescents with congenital heart diseases?

\section{Subject and methods}

\section{Research design:}

A descriptive research design was used to explore the psychosocial adjustment among adolescents with congenital heart diseases among Benha university hospital.

\section{Research setting:}

This study was carried out at cardiology department and cardiac outpatient clinic at Benha University Hospital in Benha city Qalubia governorate. The cardiology department has a capacity of 18 beds; it contains 3 wards (2femals, 1 male). The department contains 21 nurses and 40 physicians. It provides healthcare services to Qalubia, Menofia, El- Sharkia and Dakahlia governorates. It works 7days/week, 24 hours/day.

\section{Subject:}

Convenience sample constituted the study subjects. According to the information estimation program, the estimated sample size is 100 patients, at confidence level $90 \%$ and precision rate at 0.05 by using Steven equation, 2017.Since the total number of them is 230 patients.

While;

$\mathrm{P}=0.5$

$$
n=\left[\frac{N \times p(1-p)}{\left.\left.\| N-1 \times\left(d^{2} \div z^{2}\right)\right]+p(1-p)\right]}\right.
$$

$\mathrm{N}=$ Total population 
$\mathrm{Z}=\mathrm{Z}$ value "1.96"

$\mathrm{D}=$ Standard Error

$\mathrm{n}=$ sample size

\section{Inclusion criteria:}

1-Patients have congenital heart disease.

2- Both sexes.

3- Age from 10-21yeears.

4- Patients willing to participate in the study.

Exclusion criteria:

1- Free from any psychiatric diseases.

2- Free from drug use.

\section{Tools of data collection}

In order to fulfill the aim of the study, the data was collected by using the following tools:

\section{Tool I: Structured interview questionnaire:}

The questionnaire developed by the researcher based on scientific review of literature and it consists of two parts:

Part A: Socio-demographic data: to elicit data about patients characteristics such as (age, sex, occupation, educational level, residence, living arrangements, social habits, with whom you live).

Part B: Clinical data: Which includes (age at onset of disease, duration of disease, number of hospital admission, number of follow up, complications of disease, side effects of treatment, regularity of medication, family history).

Tool II: Psychosocial adjustment patterns among patients with congenital heart disease: this scale was developed by (Zaki, 2008).

It assesses the psychosocial adjustment patters used by adolescents with congenital heart disease. It includes 3 categories (51 items): avoidant patterns, seeking support and active patterns.

- Avoidant patterns: include 4 subcategories, emotional venting (6items, denial (3 items), cognitive withdrawal (5 items) and negativity (9 items).

- Seeking support: include 2 subcategories, turning to religion (4 items) and seeking social support for instrumental reason (5 items).

- Active patterns: include 4subcategories, planning (4 items), acceptance (4 items), positive interpretation (3 items) and active coping (8 items).

Scoring system:

Each answer being scored on a scale value of 0 to 2 ( $2=$ use always, $1=$ use sometimes, $0=$ use rarely), the high score mean that the patient use the pattern much and the low score mean that the patient use the pattern little. It was modified by the researcher:

0-50: indicates to little use the psychosocial adjustment pattern.

51-102: indicates to much use the psychosocial adjustment pattern.

\section{Validity of the tools:}

Tools of data collection were investigated for their content validity by panel of three experts in mental health nursing specialty to measure the validity who are selected to test content validity of the tools and to judge its clarity, relevance, comprehensiveness, understanding and applicability. The opinion was elicited regarding the layout, format and sequence of the questions and all of their remarks were taken into consideration and the tools were regarded as a valid from the experts' point of view.

\section{Reliability test of the tools:}

Reliability for tools was applied by the researcher for testing the internal consistency 
of the tools by administrating of the same tool to the same subjects under similar condition. Internal consistency reliability of all items of the tools was assessed using Cronbach's alpha coefficient.

\begin{tabular}{|l|l|}
\hline Tool & \multicolumn{1}{|c|}{$\begin{array}{c}\text { Coronbach } \\
\text { alpha test }\end{array}$} \\
\hline $\begin{array}{l}\text { Structured interview } \\
\text { questionnaire }\end{array}$ & 0.796 \\
\hline Psychosocial problem & 0.847 \\
\hline Psychosocial adjustment & 0.893 \\
\hline Total & 0.856 \\
\hline
\end{tabular}

\section{Ethical considerations:}

-The research approval of the study was obtained from scientific research ethical committee in faculty of nursing in Benha University before stating the study.

- Oral consent was obtained from each patient after explaining the purpose of the study to be participating in the study.

- Informing study subjects that confidentiality of any obtained information was ensured.

- Informing study subjects that no name was included in the questionnaire sheet.

-Respecting the right of the study sample to be withdrawn from the study at any time of data collection without any consequences.

\section{Pilot study}

A pilot study was conducted at the beginning of the study. It included 10\% (10 patients) of the total sample to estimate the needed time for data collection and to test feasibility, objectivity and applicability of the tools and the tools was adjusted according to the results of this pilot study. All subjects recruited in the pilot study meet the inclusion criteria of the study.

\section{Field work:}

- Official permission from the dean of faculty of nursing/ Benha University to the administrator of the previously mentioned setting was taken to conduct the study.

- An official approval was taken from the director of Benha university hospital.

- The researcher started data collection by introducing herself to participants.

- Written consent was obtained from every participant who fulfills the inclusion criteria.

- Data was collected through interviewing with 100 patients at cardiology department and cardiac outpatient clinic.

- The data were collected over a period of four months started from September 2020, till the end of December 2020, 3days/week, (Saturday, Sunday and Tuesday) four hours per day, from 9 am to 2 pm, nearly from ( 6-7patients ) per week . Each patient took about 30 minutes.

\section{Statistical analysis:}

The collected data were organized, coded, computerized, tabulated and analyzed by using the statistical package for social science (SPSS). Data analysis was accomplished by the use of number, percentage distribution, mean, and standard deviation, and correlation.

\section{Results}

Table (1): Demonstrates that the mean age of studied patient was 15.24(3.46) years, $52 \%$ of them were female and $75 \%$ of them from rural. This table also showed that $50 \%$ of them were intermediate education, $90 \%$ of them not working and $45 \%$ of them mother accompanying the patient in the follow-up.

Table (2): Reveals that $45 \%$ of studied patient discovered the disease at birth, $40 \%$ of them admission to hospital Furthermore and $79 \%$ of them not suffered from other disease. This table also showed that $60 \%$ of them not complain of chest pain, $65 \%$ of them not have 
any side effects from treatment that effect on their physical fitness and $87 \%$ of them received advice from the medical team regarding the treatment.

Figure (1): Illustrates that, $62 \% \& 59 \%$ of studied patient were low level about methods to seek support and avoidance adjustment methods, respectively. This figure also showed that $43 \%$ of them were high level about active adaptation methods.
Table (3): Demonstrates that, there are highly positive correlations between avoidance adjustment methods with methods to seek support at $\mathrm{p}$. value $<.000$ and active adaptation methods at $p$. value $<.004$.

Table (1): Number and percentage distribution of the studied patient's According to their socio- demographic characteristics.

\begin{tabular}{|c|c|c|}
\hline $\begin{array}{l}\text { Socio demographic characteristics of studied } \\
\text { patient's }(n=100)\end{array}$ & No & $\%$ \\
\hline \multicolumn{3}{|l|}{ Age } \\
\hline $10-<15$ & 45 & 45 \\
\hline $15-21$ & 55 & 55 \\
\hline \multicolumn{3}{|l|}{$\overline{\bar{x}}$ S.D $15.24(3.46)$} \\
\hline \multicolumn{3}{|l|}{ Gender } \\
\hline Male & 48 & 48 \\
\hline Female & 52 & 52 \\
\hline \multicolumn{3}{|l|}{ Residence } \\
\hline Rural & 75 & 75 \\
\hline Urban & 25 & 25 \\
\hline \multicolumn{3}{|l|}{ Level of education } \\
\hline Illiterate & 0 & 0 \\
\hline Read and Write & 2 & 2 \\
\hline Primary education & 30 & 30 \\
\hline Intermediate education & 50 & 50 \\
\hline University education & 18 & 18 \\
\hline \multicolumn{3}{|l|}{ Occupation } \\
\hline Working & 10 & 10 \\
\hline Not working & 90 & 90 \\
\hline \multicolumn{3}{|c|}{ The person accompanying the patient in the follow-up } \\
\hline Father & 15 & 15 \\
\hline Mother & 45 & 45 \\
\hline Father and mother & 5 & 5 \\
\hline Friend & 15 & 15 \\
\hline The patient himself & 15 & 15 \\
\hline Brother/sister & 5 & 5 \\
\hline
\end{tabular}


Table (2): Number and percentage distribution of the studied patients regarding their Clinical data

\begin{tabular}{|c|c|c|}
\hline Clinical data $(\mathrm{n}=100)$ & No & $\%$ \\
\hline \multicolumn{3}{|c|}{ Age when you discovered the disease } \\
\hline At birth & 45 & 45 \\
\hline Month & 20 & 20 \\
\hline Two month & 15 & 15 \\
\hline Year & 20 & 20 \\
\hline \multicolumn{3}{|l|}{ Pervious admission to hospital } \\
\hline Once & 10 & 10 \\
\hline Twice & 25 & 25 \\
\hline Three times & 25 & 25 \\
\hline Furthermore & 40 & 40 \\
\hline \multicolumn{3}{|c|}{ Suffer from other diseases such as } \\
\hline Coronary artery disease & 8 & 8 \\
\hline Diabetic & 4 & 4 \\
\hline Kidney failure & 2 & 2 \\
\hline chest illness & 5 & 5 \\
\hline Liver diseases and viruses & 2 & 2 \\
\hline Non & 79 & 79 \\
\hline \multicolumn{3}{|l|}{ Complain of chest pain } \\
\hline Yes & 40 & 40 \\
\hline No & 60 & 60 \\
\hline \multicolumn{3}{|c|}{ Treatment have any side effects that affect your physical fitness } \\
\hline Yes & 35 & 35 \\
\hline No & 65 & 65 \\
\hline \multicolumn{3}{|c|}{ If it finds side effects, choose from the following $\mathrm{N}=35$} \\
\hline Insomnia & 3 & 8.6 \\
\hline Blurred vision & 5 & 14.3 \\
\hline Headache & 17 & 48.6 \\
\hline hypotension & 10 & 28.5 \\
\hline \multicolumn{3}{|c|}{$\begin{array}{l}\text { Received any advice from the medical team regarding the treatment that a congenita } \\
\text { heart patient should follow }\end{array}$} \\
\hline Yes & 87 & 87 \\
\hline No & 13 & 13 \\
\hline
\end{tabular}




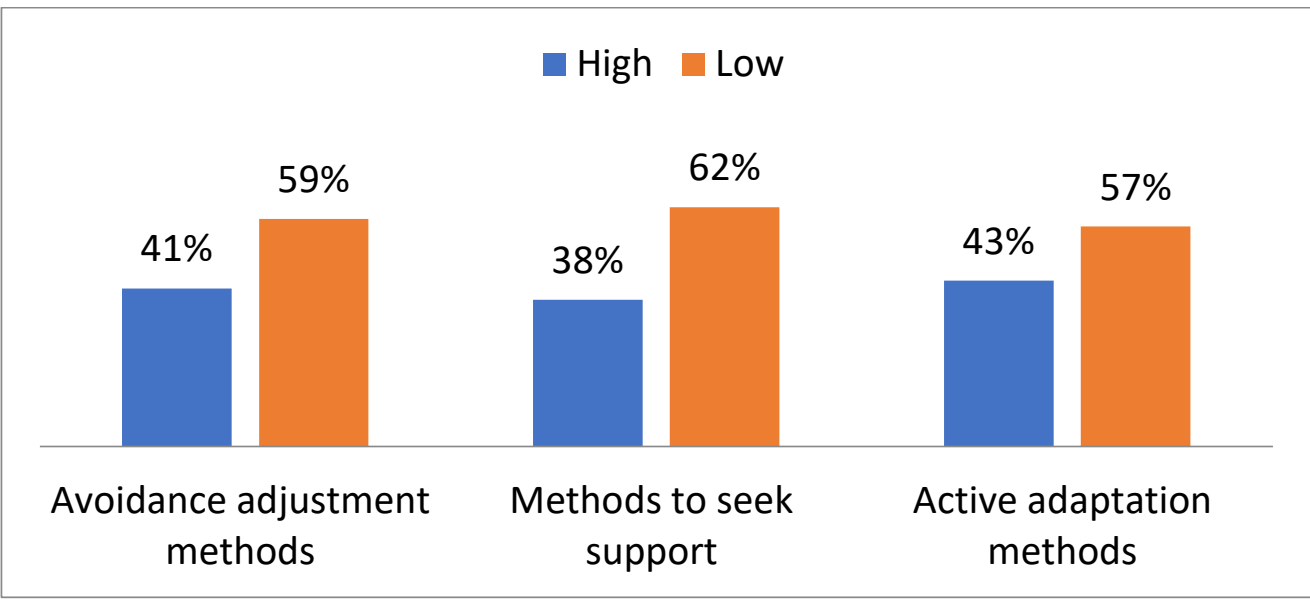

Figure (3) Percentage distribution of studied patient related their domain of patterns of psychosocial adjustment $(\mathrm{No}=\mathbf{1 0 0})$

Table (3): Correlation between domains of patterns of psychosocial adjustment

\begin{tabular}{|c|c|c|c|}
\hline $\begin{array}{l}\text { Correlation between } \\
\text { domains of patterns of } \\
\text { psychosocial } \\
\text { adjustment }\end{array}$ & $\begin{array}{c}\text { Avoidance adjustment } \\
\text { methods }\end{array}$ & $\begin{array}{c}\text { Methods to seek } \\
\text { support }\end{array}$ & $\begin{array}{c}\text { Active adaptation } \\
\text { methods }\end{array}$ \\
\hline $\begin{array}{c}\text { Avoidance } \\
\text { adjustment methods }\end{array}$ & $\begin{array}{l}\mathrm{R} \\
\mathrm{p}\end{array}$ & $\begin{array}{l}0.642 \\
.000 * *\end{array}$ & $\begin{array}{l}0.395 \\
.004 * *\end{array}$ \\
\hline $\begin{array}{c}\text { Methods to seek } \\
\text { support }\end{array}$ & $\begin{array}{l}\mathrm{R} \\
\mathrm{p}\end{array}$ & & $\begin{array}{l}0.418 \\
.002 * *\end{array}$ \\
\hline $\begin{array}{c}\text { Active adaptation } \\
\text { methods }\end{array}$ & $\begin{array}{l}\mathrm{R} \\
\mathrm{p}\end{array}$ & & \\
\hline
\end{tabular}

\section{Discussion}

Congenital Heart diseases are defined as a malformation of the heart or the large blood vessels that develops during the fetal period, and primarily structural alterations that arise due to errors in embryological development of the heart and great vessels. These resulting abnormalities range in severity from miniscule holes between chambers that may subsequently close to complex malformations that will require multiple surgical corrections to allow the affected patient to survive (Abdulla et al., 2020).
Adjusting to congenital heart disease through encourage the adolescents to make choices and participate in planning of care and scheduled activities. Participation gives a feeling of control and increases self-esteem (Azar\&Solomon, 2019). To improve the psychosocial functioning quality of life among adolescents with CHDs, helping them feel normal when managing patients' suffering. The psychiatrics suggested that a feeling of optimism was the most important 
factor in reducing CHD patients' depression and anxiety and that good social support and a strong sense of coherence were important for psychosocial stability. Good psychosocial adaptation of CHD patients appeared to be the result of close family relationships, and a strong sense of coherence (Wang et al., 2020).

Regarding the socio demographic characteristics concerning age of the studied subjects were in age group ranging from 10 to 21 years, it revealed; the mean age of them was $15,24(5,46)$ years. These findings are consistent with Clark (2019) assessed that best practices in managing transition to adulthood for adolescents with congenital heart disease. There are advances in the treatment of children with congenital heart disease have improved their life expectancy, such that nearly $90 \%$ of these children survive to adulthood. Also, this finding is similar to that two of Stanely\& Beare (2018) found that the majority of study subject were from 10to 22 years. The researcher's point of view, this result may be due to the hormonal changes which occur early in life at the time of adolescence. Also, the adolescence age had significantly more risk for developing psychological problems that result from congenital heart disease.

Concerning to sex, the present study showed that more than half of the studied subjects were females; this findings was supported by Christie \&Viner (2019) assessed that psychopathology and psychosocial adjustment in adolescents with congenital heart disease and stated the majority of the patient were females. This finding also congruent with that of Forst\&Pyorala (2018) reported that females have congenital heart diseases more females. However this findings is not in accordance with that of Shaaban\&Salem (2019) reported that in congenital heart diseases, both sexes are nearly equally affected. The researcher's opinion, this finding may be due to the cardiology department contain 3 wards are 2 female and 1 male, so almost of the patients were female.

In addition, the residence, the present study revealed that three quarters of the studied sample lives in a rural area. This result was in the same line with sable (2019) declared that prevalence of congenital heart disease was more common in rural area. The researcher's view, this result may be due to the fact that rural areas had large section of total population of Benha city. Also, this may be due to that patients living in urban areas are preferring treatment in private hospitals and take care of their health more while patients who are living in rural area mostly poor, so that they tend to resort to governmental hospitals for treatment.

Increasingly, the educational level, the result of the present study revealed that half of the studied sample were intermediate education, this may be due to that the majority of patients were fall in adolescents stage between (10-21years), these findings was supported by Freitas et al (2018) stated that the majority of patients were in school. This result contradicted with that of Pedro (2017) reported that most of patients were a high educational level and the minority of them had low level of education. The researcher's opinion, the current findings may be due to attributed to their rural culture and as a result of poverty, they care more about craftsmanship in order to make money .Also, due to the course of illness that effect on their school performance.

Concerning the working status, the majority of the studied subjects was 
unemployed. Studied patients reported that they did not work; this could be attributed to taking of medication, fatigue and exhaustion. This finding is agreement with Milunsky (2019) whose study was to assess the psychological status and quality of life of adolescents with congenital heart disease, reported that most patients with CHD were unemployed. However, this result was not in accordance with that of Alwossaby (2017) reported that patient's occupation with congenital heart disease was for the majority of patient's employers and the minorities of them were unemployed. The researcher's point of view, most of the studied patients reported that they haven't occupations; this could be the course of disease, taking of the medication at the time, fatigue and exhaustion related to the complications of the disease, decrease in concentration and activities.

Also, the person accompanying the patient in the follow up, the present study revealed that about more than two fifth of the studied sample were the mother who accompanying the patient in the follow up. This result agreed with Gill \&Liamputtong (2018) reported that the role of the mother in family health and adaptation with the illness. My opinion, this finding may be due to the mother is responsible for the everyday health and illness practices of her family especially with young children as she is the one spending the most of the time with the children due to the father being busy most of the time.so, the mother is the most person accompanying the patient to follow up.

According to the clinical data, the present data revealed that more than two fifth studied patients discovered the disease at birth, and two fifth of them admission to hospital further more. , more than three quarter of them not suffered from other disease, more than half of them not complained chest pain, more than half of them not have any side effects from treatment that effect on their physical fitness, more than three quarter of them received advice from the medical team regarding the treatment. This result was result was supported by Milunsky (2019) stated that most of patients with congenital heart disease had regressive illness, which may be due to poor follow up and less awareness of family, low economic status of most people especially in rural areas to seek medical consultation. The researcher's opinion, this findings may be due to limitation of the health education among them, low educational level and cultural values that make them using many ways to cure which cause delayed of the diagnosis and poor prognosis of the disease.

Concerning of psychosocial adjustment patterns among patients with congenital heart disease, regarding to using avoidant patterns and seek support, the present study revealed that, three fifth of studied patients were little using about methods and about two fifth of them were high using about active adaptation methods. This difference of using avoidant or seeking and active patterns of adjustment may be due to the nature of the disease which need continues follow up may extend to a lot of years and the accompanying worry about what they reached for the improving or worsening. These findings were supported by Berlopette et al (2018), assessed that quality of life and congenital heart disease in adolescents and stated some difficulties faced patients with congenital heart disease, such as; coping with the illness and physical limitations, discrimination and bullying, social exclusion, in addition to the challenge of the normality, becoming independent and uncertainty about the future and how to use coping strategies to develop self-esteem, 
among other dilemmas. The researcher's point of view, this result might be due to adolescent's with congenital heart disease cope with illness by using avoidant patterns either they sleep more than usual or they try to forget the problem completely to escape from thinking of the health problem.

As well as correlation between domains of patterns of psychosocial adjustment, the present study revealed that there were highly positive correlations between avoidance adjustment methods with methods to seek support and active adaptation methods. This results supported by Schramm (2019) whose study was to improving health- related quality of life in patients with chronic diseases such as cardiac diseases reported that there were significant relation between domains of patterns of psychosocial adjustment (avoidance adjustment methods, seeking support and active adaptation methods). The researcher's opinion, there were relation between domains of patterns of psychosocial adjustment while the adolescents get problems out of his mind and think about other things about the future and ask the medical team about the problem and how he/she deal with it.

\section{Conclusion}

Adolescents who are living with congenital heart diseases continue to face physical, psychosocial and environmental challenges. Adolescents with congenital heart disease had low level about their using patterns of psychosocial adjustment and most of them used active adaptation methods. Also, there were highly positive correlations between the total domains of psychosocial adjustment patterns.

\section{Recommendations}

- Development of educational program for adolescents patients with congenital heart disease provide them with information about medical condition and guide them with regard to physical exercises, alcohol and smoking cessation and enhance their ability to adjust with psychosocial problems.

- Establishing of educational program by nurse for adolescents patients with congenital heart disease to enhance their psychosocial adjustment and enable them to deal with their problem and enhancing their quality of life.

- Further study should be conducted on a large number of cases at other setting in order to generalize the results.

\section{References}

Abdulla, R., Blew, G., and Holterman, M. (2020). Cardiovascular embryology. Pediatric Cardiology, University of Minnesota 25, 191200. Doi: 10.1007 / s00246-003-0585-1, Available at : http: // www. Vhlab. Umn. Edu/ atlas / congenital - defects tutorial/ index . shtml. Accessed on 17-5- 2020 at 5pm.

Alwossaby,B. (2017). The impact of disability and disease duration on social support of adolescents with cardiac disease. Journal of Behavioral Medicine,25,251-268.

American Heart Association, (2018). care and treatment for congenital heart diseases, available at: http://www.heart.org/HEARTORG/ Conditions/Congenital heart diseases/Common- Types-of-Heart-DefectsUSM - 307017-Article.jsp\#. Vwphk- 1971U. Accessed on 2-5-2020 at 9pm.

American Heart Association, (2019) .Heart disease and stroke-2019 update. Dallas, Tex,: American Heart Association, 2019. 
Azar,R. and Solomon,C. (2019). Coping strategies of parents facing child with congenital heart disease. Journal of pediatric Nursing, volume 16, issue(6),pp. 418-428.

Barrat,L.(2018): Psychiatric Mental Health Nursing, $\left(2^{\text {nd }}\right.$ ed $)$, New York, pp66.

Berlopette,G.,Stovel,K., and Moos,R. (2018). Adaptation to juvenile congenital heart disease: a controlled evaluation of functional disability with one-year follow-up. Health psychol.2018;11(1): 67-76.

Christie,D. and Viner, R.(2019).Cognitive behavioral therapy targeting fear of progression in an interdisciplinary care program: a case study in systemic sclerosis. J Clin psychol Med settings.2019; 21:297-312.

Clark,D. (2019).Management of mental disorders. $1^{\text {st }}$ edn. Sydney:WHO collaborating centre for mental health. Australian and New Zealand Journal of public health. 2019;25: 494-497.

Cohen,M., Mansoor, D., Langut, H., and Lorber,A. (2019). Depressed mood, quality of life and self-esteem in adolescents with heart disease.psychosom Med.69: 313-318.

Daliento,L.(2018): Establishing trust relationship with the patients of congenital heart disease . Cardiol. 44(5): 221-228.

Forst,N. and Pyorala,C. (2018). Psychological distress following first recurrence of disease in patients with cardiac disease. 2018;61:131-7.

Freitas ,I., Castro,M., and Moura,C. (2018). A prospective study on psychosocial adaptation and psychopathology in adolescents with congenital heart disease. BMJ Open. Vol.5, Issue, 2.
Gaskin,K and Kennedy,F. (2019). Care of adolescents with congenital heart disease. Nursing standard. 2019;30(3): 50-61.

Gill,B. and Liamputtong,N.(2018).Sress, appraisal, and coping. New York. Springer.http://doi-org/10.1007/978-1-44191005-9-215.

Medical report at University Hospital, (2018). Outcome of congenital heart disease in Egyptian children, Egyptian Pediatric Association Gazette, Volume 72, Issue 2, pages 55-60.

Milunsky,F(2019). Effects of illness, role identity and competence on psychological well-being. American Journal of community psychology,25,601-627.

Pedro,S.(2017).Adjusting to chronic illness: time for a unified theory. $\mathrm{Br} \mathrm{J}$ Health psychol.2013; 18:681-686.

Sable,C. (2019). Best practices in managing transition to Adulthood for adolescents with congenital heart disease, the transition process and medical and psychosicial issues, a scientific statement from the American Heart Association, vol.123, pp.1454-1458. Available at: http://circ.ahajournals.org/content/123/13/145 4.full. Accessed on 7-3-2021 at 7.30pm.

Schramm,N. (2019). A study stressors positive coping strategies among patients with congenital heart disease. Journal of American Science; 8(5): 733-737. Available at: http://www.americanscience.org. accessed on 15-6-2020 at 7pm

Shaaban,C. and Salem,A.(2019). Psychological adjustment to chronic illness. Lancet.2019;372:246-255. 
Stanely,B. and Bear,k. (2018).Cognitive

coping strategies of adolescents with chronic

illness.J Dev. Behav. Pediatric. 2018 Aug :14(4):217-223.

Steven K. Thompson., (2017): Sampling' $3^{\text {rd }}$ ed, John Wiley \& Sons, p59-60.

Wang,Q., Clarke,D., and Menahem,S. (2020). Association between knowledge of disease, social support, sense of coherence and optimism with health related ouality of life in an ambulatory sample of adolescents with heart disease. Cardiol Younge. 25:125131.

Zaki,M.(2008). Head circumference reference data for Egyptian children and adolescents. EMHJ- Eastern Mediterranean Health Journal, 14 (1) 2008, 69- 81. Retrived from https:// apps. Who. Int/iris/handle/ 10665/ 117409. Accessed on 10/1/2020 at $10 \mathrm{pm}$. 


\section{التكيف النفسى الاجتماعى لاى المراهقين المصابين بأمر اض القلب الخلقية فى مدينة بنها}

$$
\text { سمر عزت السروى - مرفت حسنى شلبى - ضحى عبد البصير محمود }
$$

إن مرض القلب الخلقى هو مشكلة فى بنية القلب والاوعية الدموية الكبرى الموجودة عند الو لادة وتعتبر أمر اض القلب الخلقية هى أكثر أنواع الامر اض الخلقية شيو عا ويحدث بنسبة 9.01 مليون شخص عالميا ـ لذلك هدفت هذه الدراسة الى استكثاف التكيف النفسى الاجتماعى لدى المراهقين المصابين بأمر اض القلب الخلقية وقد أجريت هذه الدر اسة فى عيادة القلب وقسم القلب بمستشفى الجامعة فى مدينة بنها وقد شملت عينة الدر اسة . . مريض بسن يتر اوح ما بين · l ـ l سنة ـ ـ حيث أن المر اهقون المصابون بأمر اض القلب الخلقية معرضون لخطر كبير للاصابة بمشكلات اجتماعية ونفسية مثل تدنى إحترام الذات ، درجات أعلى من الاندفاع ، زيادت مشاعر القلق والاكتئاب ، الاستبعاد من أنشطة مجمو عة الاقران ، مشاكل فى النشاط الجنسى ، إنخفاض درجات الاستقلالية وحل المشكلات و إنخفاض مستوى جودة الحياه .لذلك من الضرورى التكيف مع هذه المشاكل النفسية و الاجتماعية التى تتتج عن أمر اض القلب الخلقبة من خلال مساعدة المر اهقين على تحديد أهداف و اقعية وتحديد المهار ات الشخصية و المعرفة أيضا تشجيع المر اهقين على التعبير عن مخاوفهم والتعبير عن المشاعر والافكار حول الوضع الحالى وتعزيز ردود التأقلم الايجابية حيث خلصت الدراسة بوجود ارتباط ذات دلاله احصائية إيجابية بين أنماط التكيف النفسي الاجتماعي الكلي للمرضى الخاضعين للار اسة. كما اوصت الدراسة بتقديم الاستشارات النفسية والاجتماعية التي يساعد فيها الدعم النفسي للمرضى وأسرهم على تحديد نقاط القوة و القدر ات والمو ارد من أجل المساهمة في التكيف الإيجابي و النتائج الصحية. 